\title{
Alkoholbruk blant ungdom i Oslo, 1970-95
}

\author{
Astrid Skretting \\ Statens institutt for alkohol- og narkotikaforskning, Dannevigsveien 10, 0463 Oslo
}

\begin{abstract}
SAMMENDRAG
Fra 1970 fram til i dag har det funnet sted en viss nedgang i andelen ungdom i alderen 15-20 år i Oslo som noen gang har drukket alkohol. På samme måte har det samlede forbruk av alkohol blant ungdom i Oslo i de senere år vist en nedgang, mens debutalderen for de ulike typer alkohol synes å ha vært stabil. Det er imidlertid bare blant gutter at alkoholforbruket har gått ned, mens forbruket blant jenter har vært mer eller mindre det samme. Det er forskjell mellom jenter og gutter i hva de drikker. Gutter drikker i hovedsak øl og brennevin, mens vin utgjør en større andel av jentenes alkoholforbruk både relativt og absolutt. Det er langt flere gutter enn jenter som oppgir hyppig beruselsesfrekvens. Utviklingen over tid viser imidlertid at mens andelen gutter med høy beruselsesfrekvens har vært stabil, er det en langt større andel jenter i dag som rapporterer om hyppig beruselse enn det vi fant for 20 år siden. Selv om det er forskjeller i sammensetningen av hva gutter og jenter drikker er det flere ting som tyder på at drikkemønsteret blant gutter og jenter ligger atskillig nærmere hverandre i dag enn det gjorde for 20-25 år siden.
\end{abstract}

Skretting A. Alcohol use among Oslo youth, 1970-95. Nor J Epidemiol 1996; 6 (1): 77-84.

\section{ENGLISH SUMMARY}

There seems to have been a decrease in the proportion of young people aged 15-20 in Oslo who have at some time drunk alcohol. Whereas début age for drinking different types of alcohol seems to have been stable, total consumption of alcohol among young people in Oslo has shown a decrease in recent years. However, it seems as though only boys have decreased their consumption. There are also many more boys than girls who report having been frequently intoxicated. However, the trend shows that the proportion of boys who have been frequently intoxicated has been stable, whereas there is a much higher proportion of girls today compared to 20-25 years ago who report having been frequently intoxicated. This means that there is much less difference in the way girls and boys drink alcohol today than there was 20-25 years ago.

\section{INNLEDNING}

Alkohol har en lang historie i vår kultur og tradisjonelt har bruk av alkohol i Norden først og fremst vært knyttet til fest og høytid. Selv om alkohol er et legalt rusmiddel, er det imidlertid klare restriksjoner for både produksjon, salg og skjenking. Blant annet må en være 18 år for å kjøpe øl og vin og 20 år for å kjøpe brennevin. Det at ungdom under 18 år ikke har lov til å kjøpe alkoholholdige drikker, forhindrer imidlertid ikke at de likevel drikker. Delvis skaffer de seg alkohol på egen hånd, delvis drikker de alkohol hjemme sammen med foreldre og annen familie. Mange unge drikker også relativt mye. Dette kan i noen grad tenkes å ha sammenheng med at bruk av alkohol framstår som en viktig del av frigjøringsprosessen for mange unge.
I den offentlige og private diskurs blir narkotika framstilt som det store rusmiddelproblemet blant ungdom. Selv om en selvsagt ikke skal bagatellisere problemene med bruk av narkotika blant ungdom i Norge, bør vi imidlertid ikke glemme at bruk og misbruk av alkohol generelt sett er et langt alvorligere samfunnsproblem. Dette gjelder bruk av alkohol blant både unge og voksne. Det kan derfor være av interesse også å følge utviklingen av alkoholbruk blant ungdom og ikke bare fokusere på narkotika.

Når vi skal beskrive ulike gruppers drikkevaner er det ikke bare hvem som drikker, hva som drikkes og hvor mye som drikkes, som er av interesse, men også hvor mye som drikkes i gitte drikkesituasjoner, i hvilken grad beruselse inngår som en del av drikkemønsteret osv. I mange sammenhenger er det snakk om et "nordisk" drikkemønster til forskjell fra et 
"kontinentalt", selv om forskjellene ikke alltid er like tydelige. Vi kan også snakke om et "feminint" drikkemønster til forskjell fra et "maskulint". Menn har f.eks. gjennom alle tider drukket langt mer enn kvinner. Det er imidlertid mye som tyder på at noe av kjønnsforskjellene er i ferd med å bli mindre tydelige enn tidligere, noe som etter alt å dømme må sees i lys av utviklingen med en større likestilling mellom kjønnene på ulike samfunnsmessige arenaer. Hvordan forholder så dette seg når det gjelder ungdom? Er det slik at forskjellene mellom gutter og jenter med hensyn til bruk av alkohol er i ferd med å forsvinne? Har utviklingen i drikkemønster mellom gutter og jenter gått i samme retning eller er det ulike utviklingstendenser?

Artikkelen søker å gi en oversikt over utviklingen av alkoholkonsum blant ungdom i alderen 15-20 år i Oslo fra 1970 fram til 1995. Den vil spesielt ta for seg om og i hvilken grad det har skjedd endringer i drikkemønster uttrykt ved totalt alkoholforbruk, fordeling mellom ulike drikkesorter, drikke- og beruselsesfrekvens og om det kan spores forskjeller i utvikling mellom jenter og gutter.

\section{MATERIALE OG METODE}

Statens institutt for alkohol- og narkotikaforskning har fra 1968 gjennomført årlige postale spørreskjemaundersøkelser blant ungdom om bruk av rusmidler og tobakk. Bakgrunnen var den allmenne bekymringen omkring bruk av cannabis og andre illegale rusmidler, men fra 1970 ble også bruk av alkohol inkludert i undersøkelsene. Spørreskjemaene blir sendt til et tilfeldig utvalg av ungdom i aldersgruppen 15-20 år. Spørreskjemaene blir besvart anonymt og svarprosenten har inntil begynnelsen av 1990-tallet stort sett ligget $\mathrm{i}$ underkant av 70 prosent. De siste par år har imidlertid svarprosenten gått ned til omkring 60 prosent. Ved en feil i utvalgsprosedyren ble utvalget for 1990 ikke representativt og er derfor utelukket fra analysene.

På grunnlag av ulike spørsmål om hvor ofte de som inngår i undersøkelsen har drukket henholdsvis $ø l$, vin og brennevin og hvor mye de drakk av de ulike alkoholsortene sist de drakk, har en beregnet årskonsumet av alkohol, omregnet til liter ren alkohol.

Slike spørreskjemaundersøkelser er alltid forbundet med visse feilkilder. Én feilkilde er at det ikke er mer enn i underkant av 70 prosent som svarer. En annen er at når man ved hjelp av spørreskjema eller intervju skal forsøke å beregne alkoholforbruket i forskjellige befolkningsgrupper, må vi vanligvis regne med at de som blir spurt, gjennomgående oppgir at de drikker mindre enn det de faktisk gjør, enten det nå skyldes glemsel, bevisst fortielse eller begge deler. Når det gjelder ungdom kan vi imidlertid tenke oss at visse forhold kan virke i motsatt retning. For det første kan det tenkes at ungdom i større grad enn voksne overdriver litt siden det for mange anses som "tøft" å tåle å drikke mye. Vanligvis drikker heller ikke ungdom så ofte som voksne og husker kanskje derfor bedre hvor mye de har drukket innen et relativt kort tidsintervall.

Slike feilkilder gjør at data fra et bestemt år kan være noe usikre. I undersøkelser hvor formålet er å belyse utviklingen over tid, er det imidlertid ikke avgjørende at data fra et enkelt år gir det helt korrekte bildet. Etter all sannsynlighet vil slike feilkilder være de samme fra år til år så lenge svarprosenten er omtrent den samme og utvalgene ellers er tilnærmet like. En vurdering av tendenser over tid skulle derfor være forholdsvis pålitelig. For en mer grundig diskusjon av metodeproblemer $\mathrm{i}$ forbindelse med estimering av alkoholforbruk henvises til Nordlund 1992 (1).

\section{RESULTATER}

\section{Hvor mange har drukket alkohol?}

Ikke overraskende viser undersøkelsene at det store flertallet av ungdom i Oslo i alderen 15-20 år har drukket alkohol (tabell 1). Det er flest som har drukket $\varnothing l$ og vin, mens noen færre har drukket brennevin. Naturlig nok skjer det i ungdomsårene en rask økning av alkoholforbruket. Som tabellen viser øker andelen unge som drikker alkohol særlig mye fra 15-16 til 1718 års alderen, men etter denne alder synes det ikke å komme til mange nye brukere. Totalt er det flere jenter enn gutter som oppgir at de har drukket ulike typer alkohol og forskjellen mellom de to kjønn er størst for vin $(\mathrm{p}<0.001)$.

Når det gjelder utvikling over tid, viser undersøkelsene at det har funnet sted en liten nedgang. På 1970- og 1980-tallet var andelen som noen gang hadde drukket alkohol omkring 90 prosent, mens den var 84 prosent $i$ årene 1993-95 samlet. Nedgangen ser ut til å henge sammen med at det er noen færre blant 15-16 åringer som rapporterer at de har drukket de senere år enn tidligere.

Tabell 1. Prosentandel som noen gang har drukket ulike typer alkohol blant gutter og jenter og i ulike aldersgrupper i Oslo, 1993-95 slått sammen.

\begin{tabular}{|l|c|c|c|c|}
\hline & $\varnothing 1$ & Vin & $\begin{array}{c}\text { Brenne- } \\
\text { vin }\end{array}$ & $\begin{array}{c}\text { Alkohol } \\
\text { totalt }\end{array}$ \\
\hline Gutter & 75 & 69 & 67 & 80 \\
\hline Jenter & 78 & 80 & 71 & 87 \\
\hline $15-16$ år & 60 & 58 & 49 & 70 \\
\hline $17-18$ år & 83 & 81 & 74 & 89 \\
\hline $19-20$ år & 87 & 85 & 82 & 91 \\
\hline Alle & 77 & 75 & 69 & 84 \\
\hline
\end{tabular}

$\mathrm{N}=1430$ 


\section{Alkoholbruk siste fire uker}

Det at ungdom har drukket alkohol noen gang innebærer ikke nødvendigvis at de drikker jevnlig. Ser vi på alkoholbruk i løpet av de fire siste ukene (tabell 2) finner vi at $i$ årene 1993-95 samlet, hadde 63 prosent drukket alkohol i en eller annen form. Øl var den mest brukte alkoholsorten siste fire uker. I alt oppga 56 prosent at de hadde drukket øl, 29 prosent vin og 26 prosent brennevin.

Tabell 2. Prosentandel blant gutter og jenter i alderen 1520 år i Oslo som oppgir å ha drukket de ulike sorter alkohol i løpet av de fire siste uker, 1993-95 slått sammen.

\begin{tabular}{|l|c|c|c|}
\hline & Gutter & Jenter & Alle \\
\hline$\varnothing 1$ & 57 & 54 & 56 \\
\hline Vin & 22 & 36 & 29 \\
\hline Brennevin & 28 & 25 & 26 \\
\hline Alkohol totalt & 61 & 65 & 63 \\
\hline
\end{tabular}

$\mathrm{N}=1430$

Det er liten forskjell mellom gutter og jenter på øl og brennevin. Den mest markante kjønnsforskjellen finner vi for vin; 36 prosent av jentene og 22 prosent av guttene rapporterte at de hadde drukket vin i løpet av de siste fire uker $(\mathrm{p}<0.001)$.

Figur 1 viser utvikling over tid for gutter og jenter. På 1970-tallet og begynnelsen av 1980-tallet var andelen som hadde drukket alkohol siste fire uker noe over 70 prosent, mens det har vært en jevn nedgang fra midten av 1980-årene fram til 1995 hvor litt over 60 prosent sett under ett, oppga å ha drukket alkohol i løpet av de siste fire uker. Som vi ser har det vært en klar forskjell i utviklingen mellom gutter og jenter.
Andelen gutter som oppgir å ha drukket alkohol i løpet av de fire siste uker, har gått jevnt ned, mens andelen blant jenter har ligget mer eller mindre på samme nivå fra omkring 1980. Det siste ti-året har det således vært flere jenter enn gutter som oppgir å ha drukket i løpet av de siste fire uker.

Det kan nevnes at det spesielt er andelen av ungdom som oppgir å ha drukket brennevin i løpet av de siste fire uker som har vist en markant nedgang. På 1970-tallet var det omkring 40 prosent som oppga at de hadde drukket brennevin, mens det i de senere år har vært en andel på omkring 25 prosent. Utviklingen har gått i samme retning både for gutter og jenter.

\section{Debut}

De som har drukket de ulike alkoholsortene har blitt bedt om å si hvor gamle de var første gang de drakk henholdsvis en flaske øl, en desiliter vin og en kvart desiliter brennevin.

Figur 2 viser at gjennomsnittsalderen for forste gangs bruk av de tre alkoholsortene øl, vin og brennevin har endret seg lite, selv om den fra å ha sunket litt i løpet av 1970-tallet ser ut til å ha gått jevnt opp fra 1980. Det er imidlertid snakk om små endringer og stort sett har debutalderen ligget rundt 14,5 år for øl, oppunder 15 år for vin og noe over 15 år for brennevin. Det har opp gjennom årene vært lite forskjell mellom jenter og gutter med hensyn til når de begynner å drikke de ulike alkoholsorter.

\section{Hvor mye drikker ungdom?}

Tabell 3 og figur 3 viser det beregnede årlige gjennomsnittlige forbruk av øl, vin og brennevin omregnet i ren alkohol for årene 1993-95 samlet. Det samlede

Figur 1. Prosentandel blant gutter og jenter $\mathrm{i}$ alderen 15-20 àr i Oslo som oppgir à ha drukket alkohol i løpet av de fire siste uker 1972-95. (Glidende 3-árig gjennomsnitt).

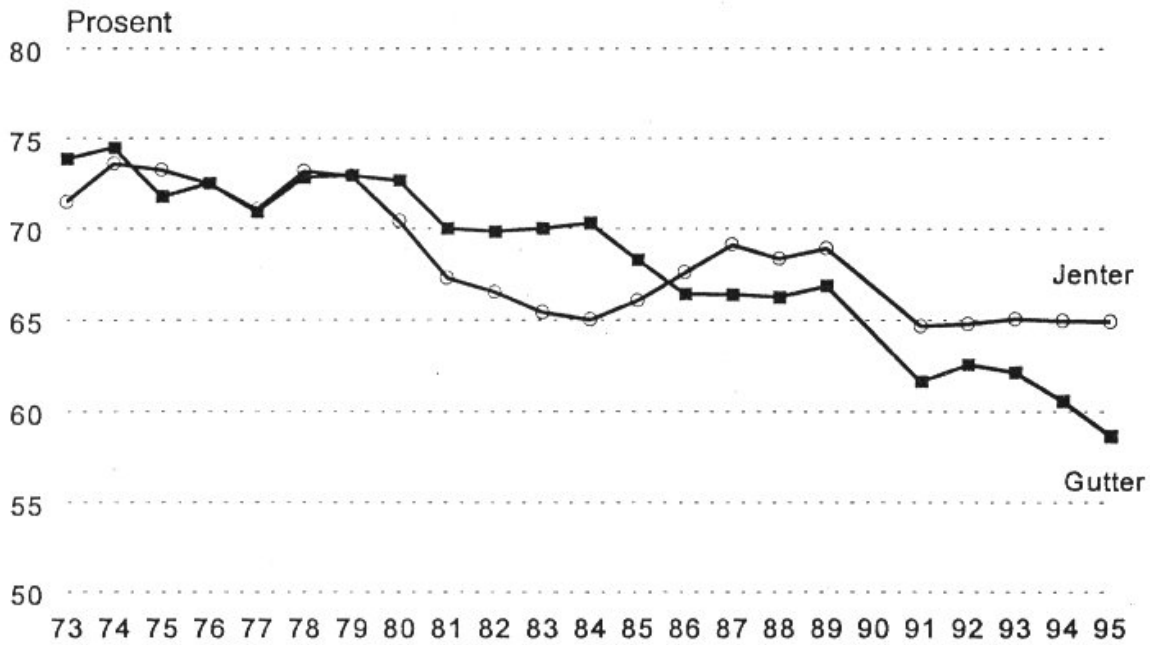


Figur 2. Gjennomsnittsalder for første gangs bruk av øl, vin og brennevin i aldersgruppen 15-år i Oslo 1972-95. (Glidende 3-årig gjennomsnitt).

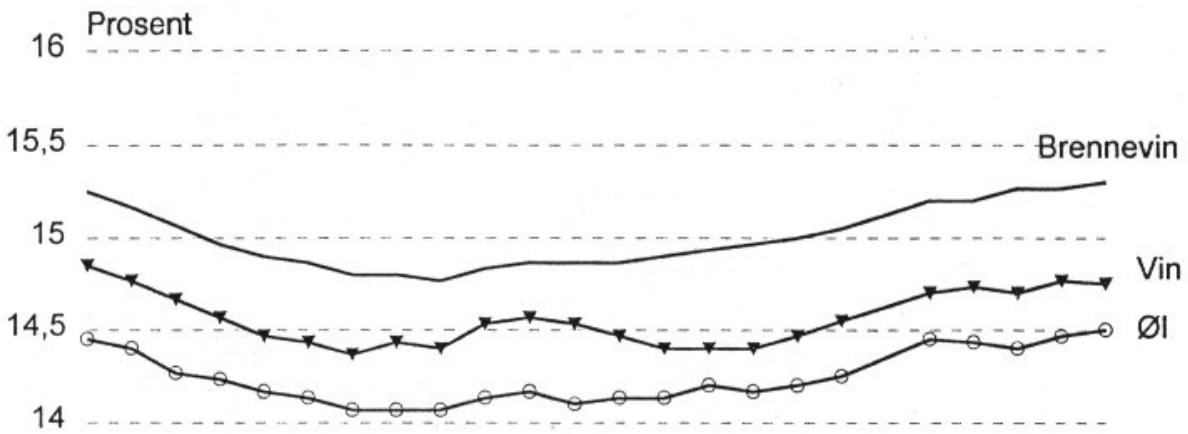

13,5

13

727374757677787980818283848586878889909192939495

alkoholforbruk er klart størst blant gutter. Gutter drikker betydelig mer av både øl og brennevin enn jenter. Når det gjelder vin er imidlertid forholdet annerledes. Jenter drikker nesten dobbelt så mye vin som gutter.

Tabell 3. Beregnet gjennomsnittlig forbruk av ren alkohol i øl, vin, brennevin og totalt i Oslo målt i antall liter for gutter og jenter, og i de ulike aldersgrupper (1993-95 slått sammen).

\begin{tabular}{|l|c|c|c|c|}
\hline & $\varnothing 1$ & Vin & $\begin{array}{c}\text { Brenne- } \\
\text { vin }\end{array}$ & $\begin{array}{c}\text { Alkohol } \\
\text { totalt }\end{array}$ \\
\hline Gutter & 2,84 & 0,28 & 0,77 & 3,89 \\
\hline Jenter & 1,67 & 0,55 & 0,34 & 2,56 \\
\hline $15-16$ år & 0,79 & 0,21 & 0,37 & 1,36 \\
\hline $17-18$ år & 2,58 & 0,40 & 0,57 & 3,54 \\
\hline $19-20$ år & 3,26 & 0,65 & 0,69 & 4,59 \\
\hline Alle & 2,23 & 0,42 & 0,55 & 3,19 \\
\hline
\end{tabular}

$\mathrm{N}=1431$

Totalt sett er imidlertid øl den mest populære drikkesorten både blant gutter og jenter. I årene 1993-95 samlet, utgjorde øl målt i liter ren alkohol, 73 prosent av alkoholkonsumet blant gutter og 65 prosent blant jenter (Figur 3). Det er for så vidt naturlig at øl har størst plass i norsk ungdoms alkoholforbruk. Totalt sett representerer øl målt i liter ren alkohol, mer enn vin og brennevin til sammen av den registrerte omsetningen av alkohol i Norge (2). Det store innslaget av øl hos ungdom avspeiler således det drikkemønster vi også finner i den voksne befolkning (3). Øl er også lettere tilgjengelig for ungdom enn vin og brennevin, ved at det etter hvert selges i de fleste dagligvarebutikker.
Mengden av øl som drikkes av ungdom i Oslo har vært nokså stabil mellom 2 og 2,5 liter ren alkohol pr. år. Vinforbruket ser ut til å ha variert noe gjennom de siste 20 år. Det var en viss økning fra 1970-tallet til slutten av 1980-tallet da forbruket lå på omkring 0,70,8 liter ren alkohol. På 1990-tallet har det vært en nedgang og det gjennomsnittlige forbruket ligger nå på under 0,5 liter. For årene 1993-95 samlet, utgjorde vin syv prosent av alkoholkonsumet blant gutter mens den tilsvarende andel blant jenter var 22 prosent (Figur 3). I samme periode utgjorde brennevin 20 prosent av forbruket blant gutter og 13 prosent blant jenter. Forbruket av brennevin ser ut til å ha gått ned fra godt over en liter ren alkohol i gjennomsnitt pr. år på 1970-tallet til omkring 0,5 liter i de senere år.

I figur 4 som viser utviklingen i det gjennomsnittlige alkoholforbruket blant ungdom i Oslo fra 1973 fram til 1995, ser vi at det på slutten av 1980-tallet fant sted en klar nedgang. Gjennomsnittsforbruket $i$ 1970-årene fram til første halvdel av 1980-årene gikk ned fra godt over fire liter til omkring 3,75 liter. I årene 1986 til 1988 var det så en liten økning igjen til rundt 4 liter, mens det var en klar nedgang rundt 1989 som har holdt seg fram til i dag, hvor det gjennomsnittlige årlige forbruket ligger på litt over 3 liter. Jenter har gjennom hele perioden hatt et langt lavere forbruk av alkohol enn gutter. Utviklingen har imidlertid vært forskjellig for gutter og jenter ved at det er totalforbruket blant gutter som har gått ned, mens forbruket har vært mer eller mindre stabilt blant jenter. Fram til slutten av 1980-tallet lå det årlige gjennomsnittlige forbruket av alkohol blant gutter på mellom 5 og 6 liter ren alkohol, mens det i de senere år har sunket til omkring 4 liter. Grovt sett kan vi si at alkohol- 
Figur 3. Beregnet gjennomsnitt årlig alkoholforbruk i ren alkohol og forbrukets fordeling på øl, vin og brennevin blant gutter og jenter, 15 - 20 år i Oslo, 1993-95 slått sammen.
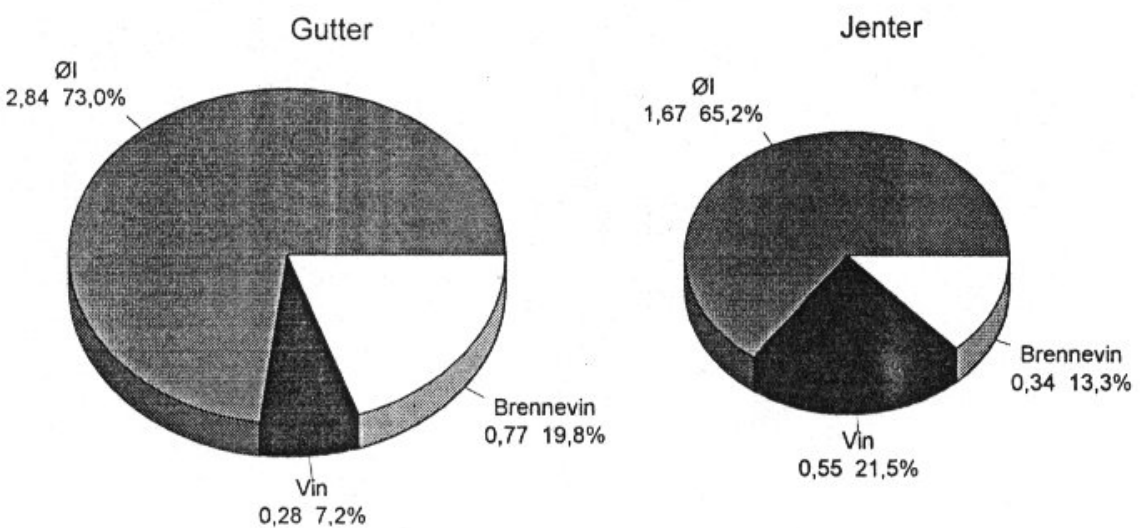

Figur 4. Beregnet gjennomsnittlig alkoholforbruk målt i liter ren alkohol blant gutter og jenter, i Oslo, 1973-95. (Glidende 3-årig gjennomsnitt).

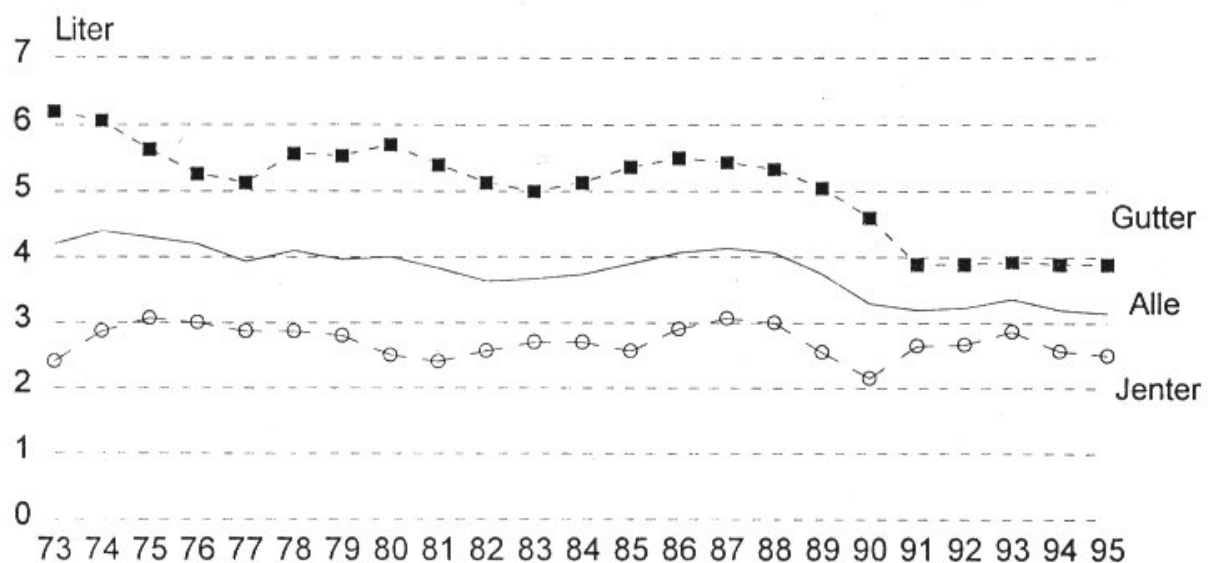

forbruket blant gutter lå på samme nivå gjennom 1970- og 1980-tallet, mens det det ser ut til å ha skjedd en klar reduksjon på slutten av 1980-tallet, og at forbruket så har stabilisert seg på et nytt lavere nivå. En slik reduksjon ser vi imidlertid ikke blant jenter. Med noen variasjoner har totalforbruket blant jenter vist et gjennomsnitt på mellom 2,4 og 3 liter ren alkohol $\mathrm{i}$ året for de mer enn 20 årene vi har data for.

Forbruket av alkohol er svært skjevt fordelt blant ungdom, slik det også er i den voksne befolkning. Det vil si at de fleste drikker lite eller ingenting, mens en relativt liten andel har et stort forbruk. Data viser at de 10 prosent av ungdommene som drikker mest, drikker mer enn halvparten av all den alkohol ungdom drikker.
Det er store forskjeller på hvor mye ungdom oppgir at de drakk ved siste drikkeanledning (tabell 4). Mange synes å ha drukket relativt beskjedent, men det må også sies å være en relativt stor gruppe som rapporterer at de drakk ganske store mengder sist de drakk alkohol. Vi gjør oppmerksom på at det ikke foreligger opplysninger om hvorvidt ungdom har drukket mer enn en type alkohol i samme drikkesituasjon, noe som ofte vil være tilfelle.

Det framkommer klare kjønnsforskjeller for hvor mye en har drukket av de ulike alkoholsorter ved siste drikkesituasjon. Guttene har f.eks. i langt større grad enn jentene oppgitt at de drakk seks flasker øl eller mer sist de drakk øl. Det var også langt flere gutter enn jenter som oppga at de hadde drukket $20 \mathrm{cl}$ brennevin eller mer sist de drakk brennevin. Når det 
gjelder vin derimot er det flere jenter enn gutter som oppgir at de har drukket så mye som en hel flaske eller mer sist de drakk vin.

Tabell 4. Prosentandel blant gutter og jenter og i de ulike aldersgrupper i Oslo som oppgir å ha drukket henholdsvis 5-6 halvflasker øl eller mer, en helflaske vin eller mer eller $20 \mathrm{cl}$ brennevin eller mer, siste gang de drakk de ulike typene alkohol, 1993-95 slått sammen.

\begin{tabular}{|l|c|c|c|}
\hline & $\begin{array}{c}6 \text { halvflasker } \\
\varnothing l+\end{array}$ & 1 flaske vin+ & $\begin{array}{c}20 \mathrm{cl} \\
\text { brennevin }+\end{array}$ \\
\hline Gutter & 34 & 11 & 28 \\
\hline Jenter & 15 & 17 & 18 \\
\hline $15-16$ å & 12 & 11 & 14 \\
\hline $17-18$ år & 29 & 15 & 25 \\
\hline $19-20$ å & 31 & 17 & 29 \\
\hline Alle & 24 & 14 & 23 \\
\hline
\end{tabular}

$\mathrm{N}=1438$

\section{Beruselse}

Om og hvor ofte det drikkes så mye at en tydelig kjenner seg beruset, inngår i beskrivelsen av ulike drikkemønstre. Etter alt å dømme vil det være noe ulikt hva forskjellige personer legger i det å ha kjent seg beruset. Det kan f.eks. tenkes at gutter og jenter har noe ulik fortolkning. En kan imidlertid regne med at dette ikke har forandret seg noe vesentlig over tid.

I årene 1993-95 samlet, var det så mange som to tredjedeler av ungdommen i Oslo som oppga at de hadde kjent seg tydelig beruset i løpet av de siste seks måneder (tabell 5). Det var ingen nevneverdig forskjell mellom gutter og jenter. Det var imidlertid flere gutter enn jenter som oppga at de hadde følt seg tydelig beruset mer enn 25 ganger i løpet av de siste seks måneder $(\mathrm{p}<0.005)$. Tabellen viser også at det skjer en økning i beruselseshyppighet med økende alder. I aldersgruppa 15-16 år oppga halvparten at de hadde vært tydelig beruset i løpet av de siste seks måneder, mens andelen i de to eldste aldersgruppene var omkring tre fjerdedeler.

Tabell 5. Prosentandel blant gutter og jenter og i de ulike aldersgrupper i Oslo som oppgir at de tydelig har kjent seg beruset i løpet av de seks siste måneder, 1993-95.

\begin{tabular}{|l|c|c|}
\hline & $\begin{array}{c}\text { Beruset } \\
\text { noen gang }\end{array}$ & $\begin{array}{c}\text { Beruset 25 } \\
\text { ganger }+\end{array}$ \\
\hline Gutter & 65 & 10 \\
\hline Jenter & 69 & 6 \\
\hline $15-16$ år & 47 & 2 \\
\hline $17-18$ år & 74 & 8 \\
\hline $19-20$ år & 78 & 13 \\
\hline Alle & 67 & 8 \\
\hline
\end{tabular}

$\mathrm{N}=1434$

Figur 5 viser utviklingen over tid når det gjelder det å ha vært tydelig beruset mer enn 50 ganger. Det er en klar forskjell mellom gutter og jenter. Langt flere gutter enn jenter oppgir å ha vært beruset så mange ganger. Utviklingen for gutter og jenter har imidlertid vært noe ulik. Mens andelen gutter som oppgir å ha vært beruset så ofte, stort sett har ligget omkring 25 prosent, har andelen jenter som oppgir at de har vært beruset mer enn 50 ganger, økt fra mindre enn 10 prosent på begynnelsen av 1970-tallet til mer enn 15 prosent på 1980- og 1990-tallet. Forskjellen mellom gutter og jenter er med andre ord mindre i dag enn for 20 år siden når det gjelder å ha vært ofte beruset.

Figur 5. Andel av gutter og jenter, 15-20 år, i Oslo 1970-95 som oppgir at de har kjent seg tydelig beruset av alkohol mer enn 50 ganger. (Glidende 3-árig gjennomsnitt).

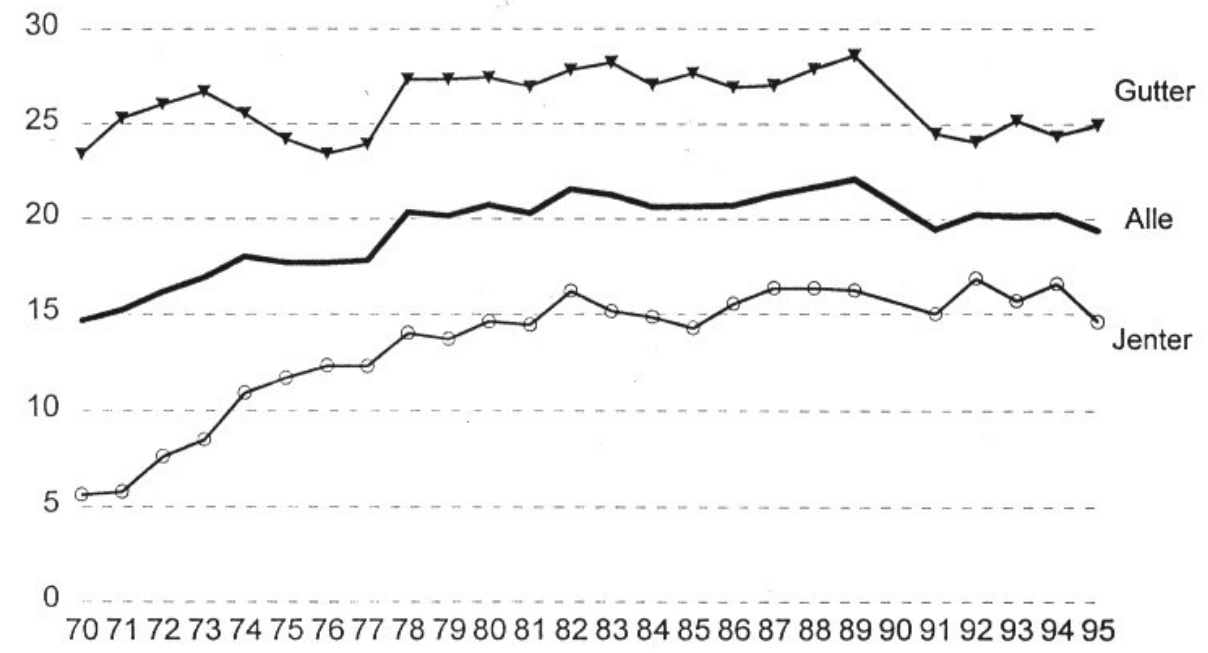




\section{DISKUSJON}

Det synes å ha funnet sted en viss nedgang $\mathrm{i}$ andelen av ungdom i alderen 15-20 år i Oslo som noen gang har drukket alkohol. Det er imidlertid begrenset hva dette forteller om alkoholvaner blant ungdom. Hvor mye, hvor ofte og hva som drikkes, og i hvilken grad bruk av alkohol fører til beruselse, er derimot viktige opplysninger i beskrivelsen av ungdoms alkoholvaner og endringer i disse.

Mens debutalderen for de ulike typer alkohol synes å ha vært stabil, har det samlede forbruk av alkohol blant ungdom i Oslo de senere år vist en nedgang. Etter alt å dømme har dette sammenheng med en allmenn nedgang i alkoholkomsumet i Norge i disse årene. Det ser imidlertid ut til at det bare er gutter som har redusert sitt forbruk, ved at forbuket av alkohol blant gutter har gått ned med omkring en tredjedel fra omkring 6 liter til omkring 4 liter i løpet av de siste 20 årene. Forbruket har ikke vist en slik nedgang blant jenter. Dette har således ført til at det gjennomsnittlige alkoholforbruket hos gutter og jenter ligger atskillig nærmere hverandre i dag enn det gjorde for 20-25 år siden.

Det er forskjell mellom jenter og gutter i hva de drikker. Gutter drikker i hovedsak $ø l$ og brennevin, og i mindre grad vin. Mesteparten av alkoholen jenter drikker er også øl, men jenter drikker klart mer vin (både relativt og absolutt) og mindre brennevin enn det gutter gjør. Dette er et mønster vi finner enten vi ser på samlet alkoholkonsum, hva som er drukket i løpet av de siste fire uker og hvor mye som ble drukket ved siste drikkesituasjon. Det er også langt flere gutter enn jenter som oppgir hyppig beruselsesfrekvens. Utviklingen over tid viser imidlertid at mens andelen gutter med høy beruselsesfrekvens stort sett har vært stabil, er det en langt større andel jenter i dag som rapporterer om hyppig beruselse enn det vi fant for 20 år siden. Selv om gutter drikker mindre enn tidligere har det likevel ikke skjedd noen tilsvarende reduksjon i antall tilfeller av beruselse. Blant jenter ser vi at antall rapporterte tilfeller av beruselse har $ø k t$, selv om det ikke har skjedd noen økning i alkoholkonsum. Dette er vanskelig å forklare, men kan tyde på at det har skjedd en utvikling i retning av at alkoholkonsumet hos både gutter og jenter er mer orientert mot beruselse enn det som var tilfelle tidligere. Hvis dette medfører riktighet er det mye som tyder på at drikkemønsteret på en måte har blitt mer "maskulint" både blant gutter og jenter.

\section{Ulik utvikling hos gutter og jenter}

Tradisjonelt har kvinner i Norden hatt et langt lavere alkoholkonsum enn menn. Selv om kvinner fremdeles drikker mindre alkohol er det imidlertid flere nordiske studier som viser at alkoholkonsumet blant kvinner de siste ti år har vært økende og at kvinner i en viss grad utvikler særegne drikkevaner (4). Utviklingen vi ser blant ungdom i Oslo ser i noen grad ut til å gå i samme retning.

Hvor skal vi lete etter forklaringer på forskjellen i utvikling i alkoholvaner blant gutter og jenter? I lys av teorier om drikkekulturens kollektive karakter skulle en kanskje kunne forvente at alkoholforbruket blant gutter og jenter utviklet seg mer i samme retning? I stedet ser vi at jenter - i motsetning til gutter - ikke har redusert sitt alkoholforbruk slik at jenter relativt sett, sammenlignet med gutter, drikker foholdsvis mer enn det de gjorde tidligere. Kan dette tyde på at det til en viss grad er snakk om ulike kollektive drikkekulturer blant gutter og jenter?

En grunn til at kvinner i Norden generelt drikker mer enn før, kan etter alt å dømme tilskrives nye samfunnsmessig akseptable måter for kvinner å omgås på, ikke minst når de er sammen med andre av samme kjønn. Et illustrerende eksempel er venninner $i$ alle aldre som i dag møtes over en flaske vin enten hjemme eller på kafé, i stedet for som tidligere over den mer tradisjonelle kaffe- eller tekoppen. Det er nærliggende å tenke på denne endringen som en funksjon av kvinnenes generelle økende deltagelse på ulike samfunnsmessige arenaer. Som på andre områder blir det også større likhet i rammene rundt de sosiale møter mellom kvinner og menn. Menn har som kjent gjennom årtier møtt hverandre over en øl eller flere. Selv om vi ikke kan se noen økning i alkoholforbruket blant jenter i Oslo kan det likevel være mulig at denne type "nye" omgangsformer en generelt kan finne blant kvinner, kan forklare noe av det faktum at jenter i Oslo ikke har redusert sitt alkoholfobruk slik en skulle forvente når vi ser på alkoholforbruket blant gutter.

At jenter i Oslo drikker mer vin enn gutter er noe vi også finner $\mathrm{i}$ andre nordiske studier (4). Norge sammen med resten av Norden tilhører tradisjonelt en sprit- og ølkultur. Den mannlige delen av befolkningen holder seg også stort sett innenfor de tradisjonsfestede alkoholtyper. Hvorfor velger kvinner i Norden i større grad enn menn en "ny" alkoholsort som vin? For folk flest i Norden må vindrikking sies å være et relativt nytt fenomen.

En grunn til denne forskjellen kan være at kvinner generelt er mindre tradisjonsbundne enn menn, og således har lettere for å ta opp impulser fra andre kulturer. Når det gjelder utvikling av alkoholvaner kan det også spille inn at kvinner allment har hatt et langt lavere alkoholforbruk slik at de derfor har stått kulturelt friere $\mathrm{i}$ å velge når de for alvor inntok alkoholarenaen. Det at kvinner i stor grad drikker alkohol i forbindelse med måltider samtidig som vin også i Norden i stadig sterkere grad inngår som måltidsdrikke, kan også bidra til at kvinner relativt sett drikker mer vin enn menn.

Det er også hevdet at den moderne kvinnes forhold til alkohol ikke nødvendigvis formes ut fra et mannlig mønster, men som en del av utviklingen av et 
eget kvinnebilde (5). Dette dreier seg ikke bare om kvinnens frigjøring og individualisering i forhold til mannen, men at det tradisjonelle kvinnebildet brytes ned og et nytt tar form. Det nye kvinnebildet kan også innbefatte en måte å bruke alkohol på som oppleves som spesifikt kvinnelig.

Skal vi så være bekymret over at jenter i Oslo ser ut til å nærmer seg gutter når det gjelder forbruk av alkohol selv om de ikke ser ut til å drikke mer enn tidligere? Ut fra et skadeperspektiv er det selvsagt ønskelig at det drikkes minst mulig både blant jenter og gutter. Fra et feministisk synspunkt kan det imidlertid være fristende å se et positivt element $\mathrm{i}$ at forkjellen mellom gutter og jenter reduseres også på dette området. At det i det lange løp kan medføre negative helsemessige og sosiale konsekvenser kan således bli en omkostning man eventuelt må være villig til å ta med på kjøpet.

\section{REFERANSER}

1. Nordlund S. Metoder og metodeproblemer ved estimering av alkoholforbruk. SIFA rapport nr. 3/92, Oslo, 1992.

2. Grytten L. Rusmidler i Norge. Rusmiddeldirektoratet og SIFA, Oslo, 1995.

3. Saglie J. Norske drikkekulturer: Geografi, sosial bakgrunn, livsstil og tilgjengelighet. SIFA rapport $\mathrm{nr}$ 1/94, Oslo, 1994.

4. Järvinen M, Rosenqvist P. Kön, Rus och Disciplin. NAD-publikation nr. 20, 1991.

5 Paakkanen P. Könens dubbla medborgarskap och alkoholen. NAT nr. 3, 1992. 